\title{
Mycobionta of birch and birch stump roots and its possible effect on the infection by Armillaria spp. I.
}

\author{
HANNA KWAŚNA \\ Department of Forest Pathology, University of Agriculture, ul. Wojska Polskiego $71 \mathrm{c}$, \\ 60-625 Poznań, Poland
}

$\mathrm{K} w$ a $\$ \mathrm{n}$ a $\mathrm{H}_{\mathrm{A}}$ : Mycobionta of birch and birch stump roots and its possible effect on the infection by Armillaria spp. I. Acta Mycol. 31 (1): 101-110, 1996.

Zygorhynchus moelleri was the dominating species on/in roots of 2 year-old stumps of the 49 year-old birches. Trichoderma viride was more frequently found in the fine roots of living birches than in the fine roots of stumps though its population increased in thick roots of stumps. Occasionally the fungus also occurred on the surface of fine roots of stumps. Z moelleri is known to produce indole 3 -ethanol and indole-3 acetic acid which stimulate the growth of A. ostoyae rhizomorphs and phenoloxidizing enzymes which play an important role in the degradation of the wood. It seems that the accumulation of $Z$ moelleri and absence of bigger populations of $T$. viride on/in roots of 2-year-old stumps of the 49 year-old birches may result in an increase of their susceptibility to Amillaria infection.

Key words: Amillaria, birch, mycobionta, roots, stumps, Zygorhynchus.

\section{INTRODUCTION}

Root rot caused by Armillaria spp. is known to be associated with many species of trees and their stumps, but the common opinion is that hardwood stumps provide a better substrate than the living deciduous trees. D i $\mathrm{m}$ i t $\mathrm{r}$ i (1969) indicated that Armillaria infection which may take place through healthy, undamaged roots, primarily occurs through wounds and dead roots. This is in agreement with the findings of Wh it n e y (1961), K i 1 e (1981), B a s h a m (1988) as well as R i z z o, H a rr i n g t o n (1988). Our current understanding of what stimulates and controls penetration and colonization of the substrate by Armillaria is incomplete. It is difficult to determine by observation the role of particular factors affecting the infection. It seems, however that the specific mycobionta of the dead roots which are the main "route" of infection of stumps may increase their susceptibility. Both the density of saprophytic fungi population and the type of metabolites produced must be taken into account. This paper presents differences in the structure of mycobionta communities occurring on/in roots of birch (Betula verrucosa) and roots of its stumps. 
It seems that the mycobionta on the latter may stimulate the infection by Armillaria. Birch was selected for these studies as it is the dominating admixture species in the forests of western Poland.

\section{MATERIAL AND METHODS}

In September 1991 roots were collected from 49-year-old birches in Huta Pusta Forest District (western Poland, $17^{\circ} 10^{\prime} \mathrm{E}, 52^{\circ} 50^{\prime} \mathrm{N}$ ), division $37 \mathrm{~h}$. The birch comprised $10 \%$ of the Scots pine stand. Trees were cut down and after 2 years roots were collected from their stumps. Three root complexes, each about $30 \mathrm{~cm}$ long, lying $120^{\circ}$ apart from each other, were excavated from B-horizon $(30-50 \mathrm{~cm})$ under each of the 5 healthy trees and stumps. In laboratory 3 to 5 randomly selected segments of fine roots $(0.5-1 \mathrm{~mm}$ in diam.) and 1 segment of thicker root $(5 \mathrm{~mm}$ in diam.), $2 \mathrm{~cm}$ long were excised from each root complex. The soil ( $\mathrm{pH} 4.65$ ) samples were taken from beneath the roots of each tree and stump. In the laboratory single soil samples were mixed together. Isolation of soil, rhizoplane, rhizosphere and root fungi was carried out according to $M$ a ń $k$ a (1974). The root segments were washed 10 times for $3 \mathrm{~min}$. The first 8 and the 10 th flask contained $100 \mathrm{ml}$ of distilled sterile water, the 9 th contained $70 \mathrm{ml}$ of distilled sterile water and $30 \mathrm{~g}$ of sterile quarz sand. The suspension from the 1st and the 1Oth flask were used for isolation of fungi from rhizoplane and rhizosphere, respectively. One drop of the suspension (diluted for rhizoplane fungi) was placed on the surface of the cooled medium $\left(\mathrm{KH}_{2} \mathrm{PO}_{4}-1 \mathrm{~g}\right.$, $\mathrm{MgSo}_{4} \times 7 \mathrm{H}_{2} \mathrm{O}-0.5 \mathrm{~g}$, peptone $-5 \mathrm{~g}$, dextrose $-10 \mathrm{~g}$, rose bengal $-10 \mathrm{ml}, 0.3 \%$ chlorotetracycline $0.004 \mathrm{~g} \mathrm{1}^{-1}$, agar $-20 \mathrm{~g} \mathrm{1}^{-1}$ ) in the centre of $9 \mathrm{~cm}$ in diam. Petri dish and spread carefully on the entire surface. The isolation of rhizoplane and rhizosphere fungi was carried out on 30 Petri dishes each. Roots were dried on the sterile filter paper. The fine roots were divided into $5 \mathrm{~mm}$ long subsegments and the thick ones into $1 \mathrm{~mm}$ thick discs which were put onto $2 \%$ PDA agar with chlorotetracycline $\left(0.004 \mathrm{~g}^{-1}\right.$ agar). Each type of roots was represented by 180 inocula placed on 30 Petri dishes (6 per $1 \mathrm{dish}$ ). The fungi were incubated at $20-22^{\circ} \mathrm{C}$, subsequently transferred into test tubes with PDA for conservation and identified according to their morphology on SNA, PDA, Czapek-Dox and $2 \%$ Malt-extract agar.

\section{RESULTS}

Table 1 presents a list of all fungi isolated from the soil, rhizoplane, rhizosphere, fine and thick roots of the 49-year-old birch and its stumps two years after cutting of the trees. Altogether 91 species of fungi were identified. Table 2 gives the frequency of the most common taxa in soil/root habitat of tree and stump roots. The total number of isolates obtained from the soil surrounding the roots of live trees and stump was 580 and 159 , respectively. The soil fungi communities were represented by 23 
species. The most common were: Mortierella vinacea, Penicillium daleae, P. adametzii and $P$. janczewskii. Except for the last species the frequency of the remaining fungi decreased in soil beneath the stumps. Among species which occurred frequently were $P$. spinulosum, $P$. montanense and $P$. steckii which were detected only in the soil of the stump roots. They partly accounted for the increase of Penicillia density in the soil beneath the stumps. In the soil beneath the roots of living trees and their stumps Penicillia were represented by a similar number of species.

The rhizoplane and rhizosphere of birch roots were inhabited by 451 and 124 isolates represented by 26 and 14 species, respectively. On the roots of stumps the density of fungi was much higher and the total number of isolates amounted to 3056 and 295 in rhizoplane and rhizosphere, respectively. In the rhizoplane this large community was represented only by 19 species. In the rhizosphere of the stump roots the number of species increased to 21. Acremonium spp. occurred only in the rhizoplane of the live roots. Except for A.kanagawaensis whose single isolates were detected in the rhizosphere of stump roots, other Aspergillus species inhabited only the surface of the live roots. The frequency of Mucorales increased to $64.7 \%$ and $10.9 \%$ of the total number of isolates in the rhizoplane and rhizosphere of the stump roots. The most common species was Z moelleri. In the rhizoplane of the stump roots the fungus comprised over $50 \%$ of the total number of isolates detected. Considering the size of the fungi community, the population of the fungus was extremely large. In the rhizosphere its frequency was lower and comprised only $3.4 \%$ of all the isolates. Compared to the live roots, the frequency of Penicillia decreased to $33.4 \%$ and increased to $78.9 \%$ of the total numer of isolates in rhizoplane and rhizosphere of the stump roots, respectively.

Compared to the roots of living trees, the number of isolates from fine and thick roots of stumps increased over $36 \%$ and $158 \%$ and was 377 and 334 , respectively. In the fine and thick roots of stumps the frequency of Mucorales increased to 27.8 and $41.3 \%$ of the total number of isolates. Except for Mortierella vinacea, which in the fine roots of stumps occurred with similar density as in the fine roots of the living trees, the most common species was Zygorhynchus moelleri. The fungus accounted for $15 \%$ and $39 \%$ of the total number of isolates in fine and thick stump roots, respectively. It was the most common species in the thick roots. Compared to the roots of living trees, the density of Penicillia was stable in fine roots and increased markedly in the thick roots. Mycelium radicis atrovirens which was the dominating species in the thick roots of the live trees, occurred with much lower frequency in the fine and thick roots of stumps. Cylindrocarpon destructans was found mostly in fine roots of live trees and more frequently in the thick roots of stumps. Oidiodendron species were isolated from the soil and rhizoplane of the live tree roots. Sporadically the fungi also occurred on the surface of the stump roots. Only single isolates of Trichoderma spp., occurred in the soil and on the surface of stump roots. Fungi were present more frequently in the fine roots of the living trees and in the fine and thick roots of stumps. 


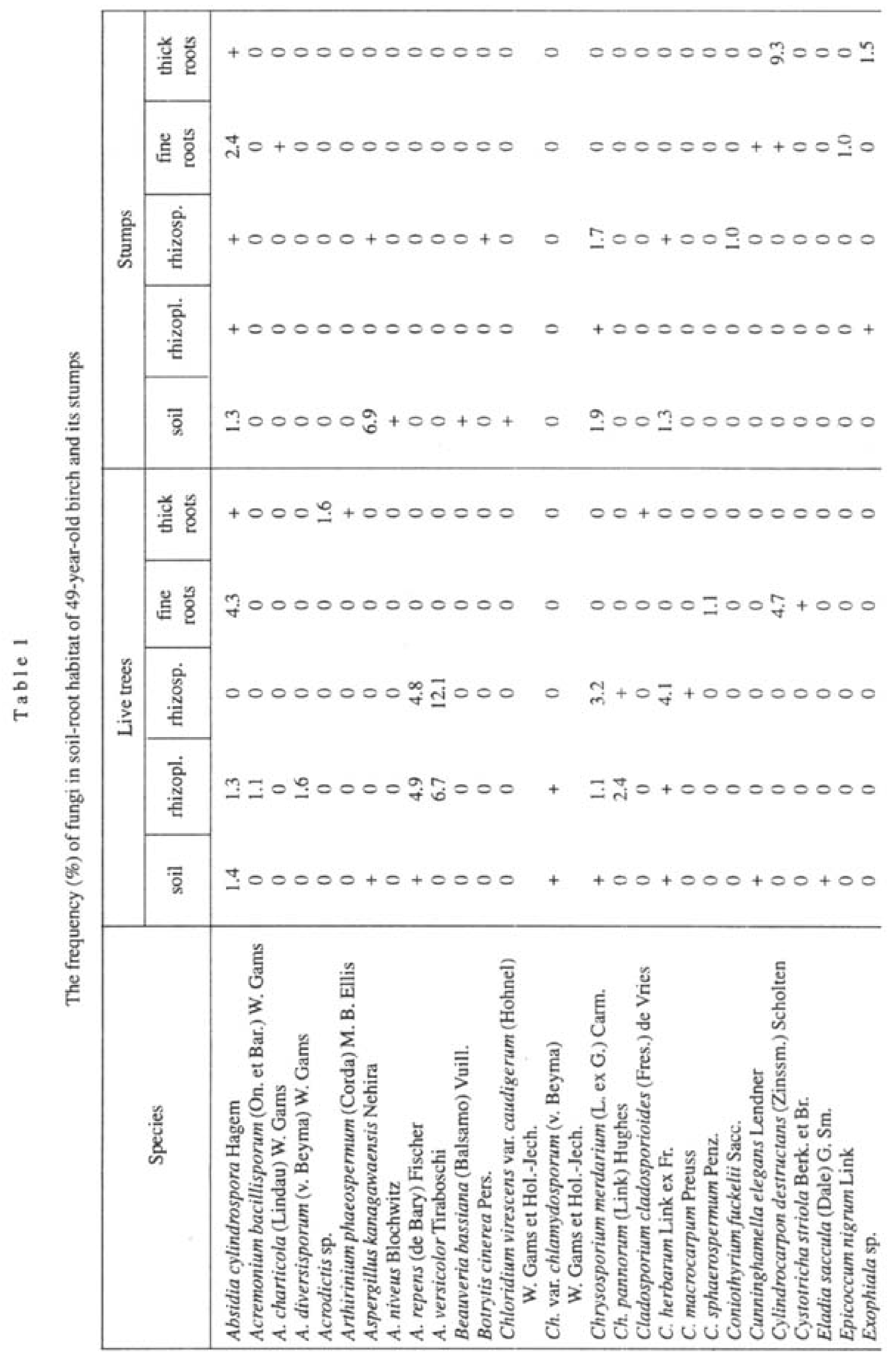


$000++0000++0$ V00000+00000

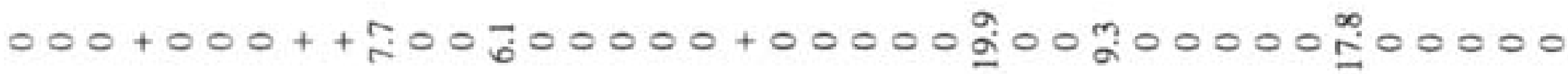

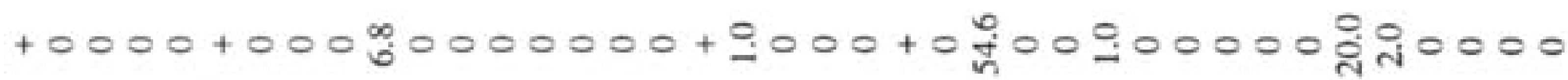
$0000+0000 \frac{1}{0}+00000000+000 \underline{1}+0+00000 \underline{1}+000++$

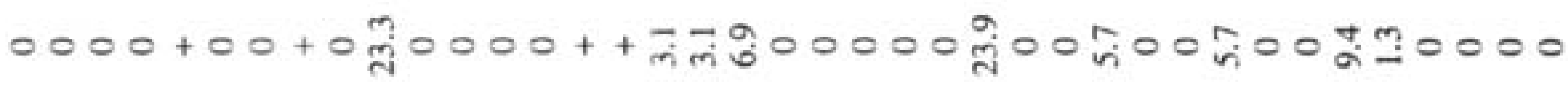
000000000 M00

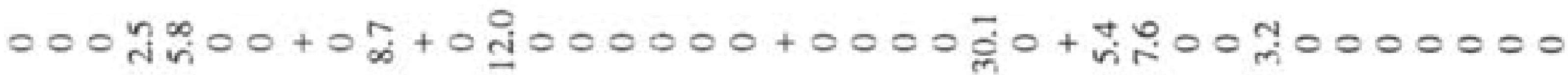
$0000+0000$ ห่०00000000

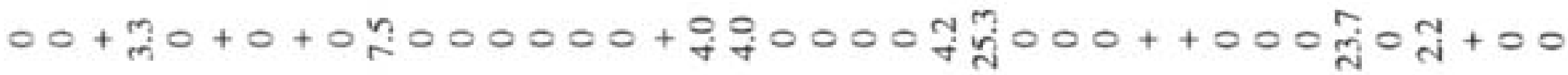

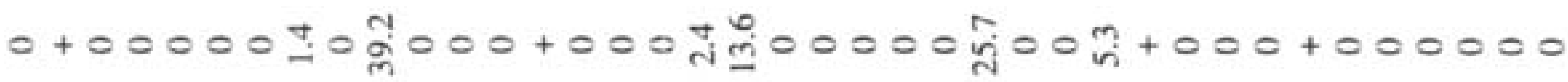

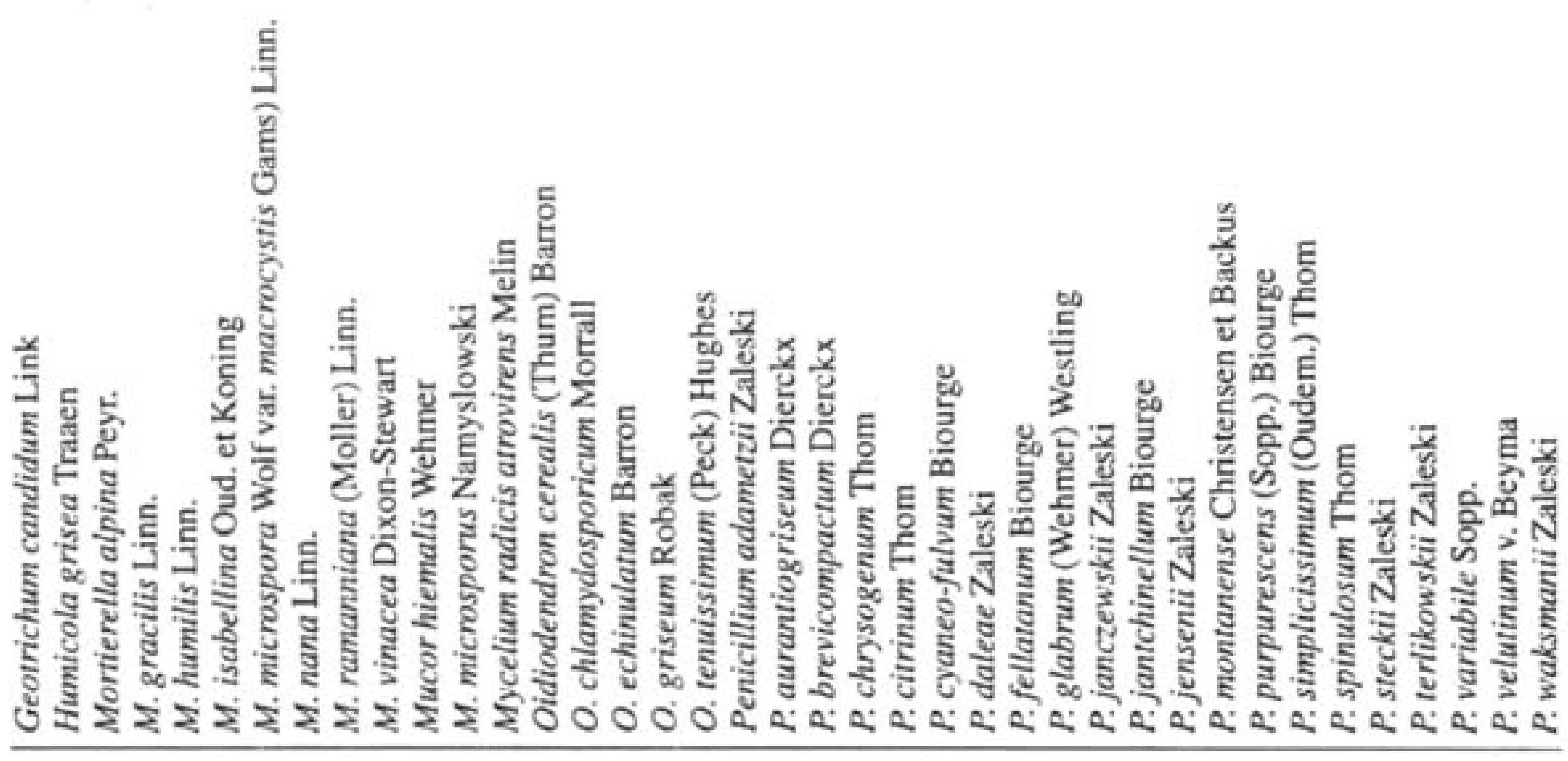




\begin{tabular}{|c|c|c|c|c|c|}
\hline \multirow{5}{*}{ 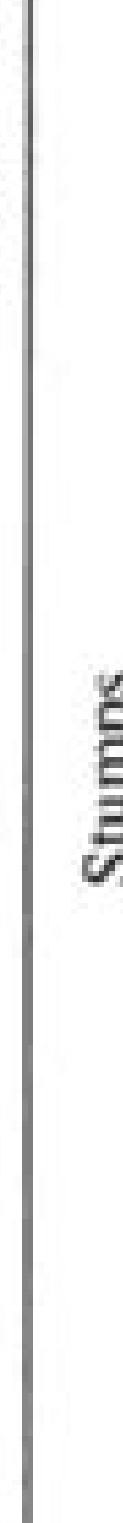 } & 意宽 & +00000000 I & 20000 & 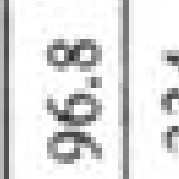 & 9 \\
\hline & 道量 & $000000+000000000 \underline{0}++0$ & $\underline{\underline{s}}=000$ & ะू & 点 \\
\hline & 竞 & $0 \bar{y}=00000000+00000000$ & 芦0000 & 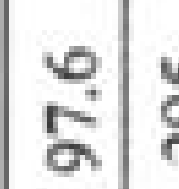 & הิ \\
\hline & 产 & $0000000000+000$ & तें०000 & $8:$ & : \\
\hline & 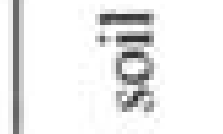 & $000000000000++000000$ & +0000 & $\Sigma^{\infty}$ & ดे \\
\hline \multirow{5}{*}{ 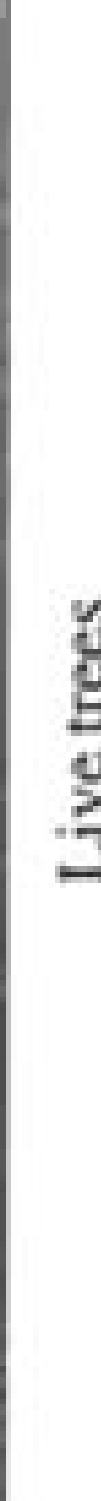 } & 童 & $000 \overline{\mathrm{m}} 0000000000000000$ & $0 \stackrel{0}{=00+}$ & 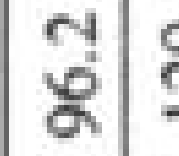 & a \\
\hline & 崖营 & 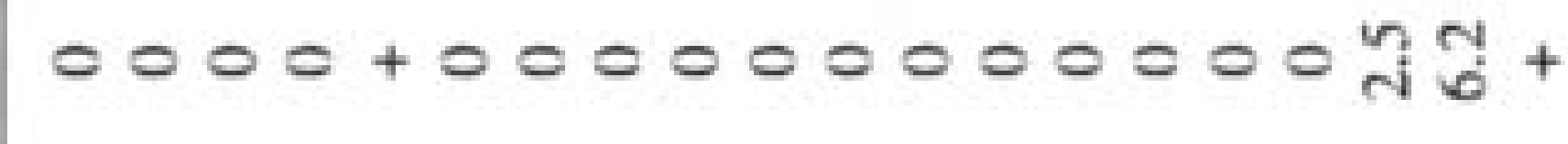 & 20000 & 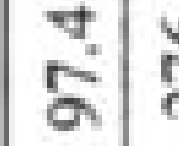 & : \\
\hline & 潒 & $00000+00700000000000$ & 00000 & : & 政 \\
\hline & 童 & 00000000000000000000 & $\stackrel{0}{-}=0+0$ & से & : \\
\hline & 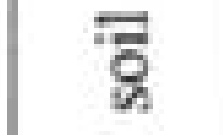 & $00000 \overline{4} 000000$ M $00000+0$ & $+0+00$ & 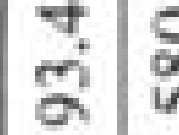 & ก \\
\hline \multicolumn{2}{|r|}{ 总 } & 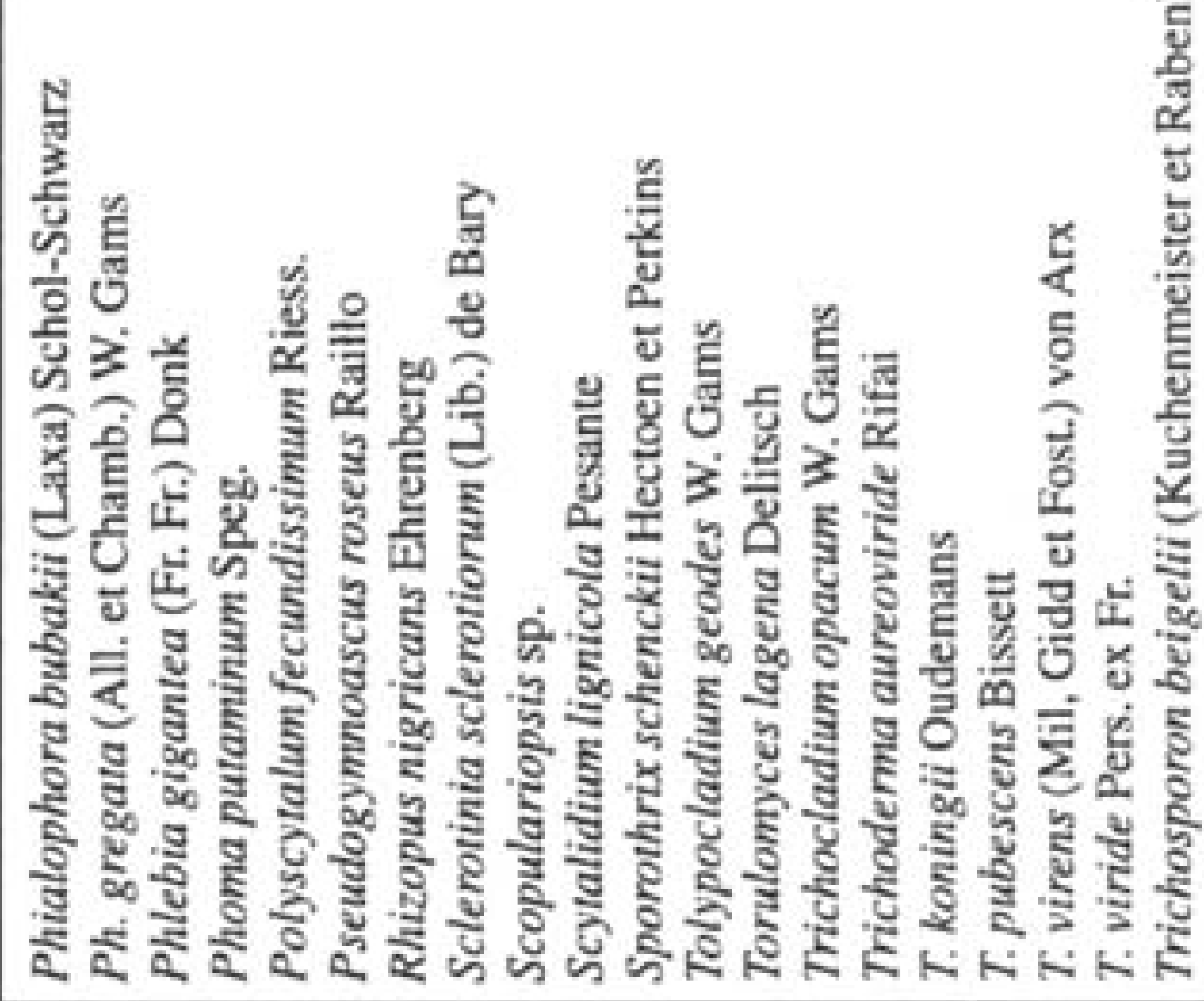 & 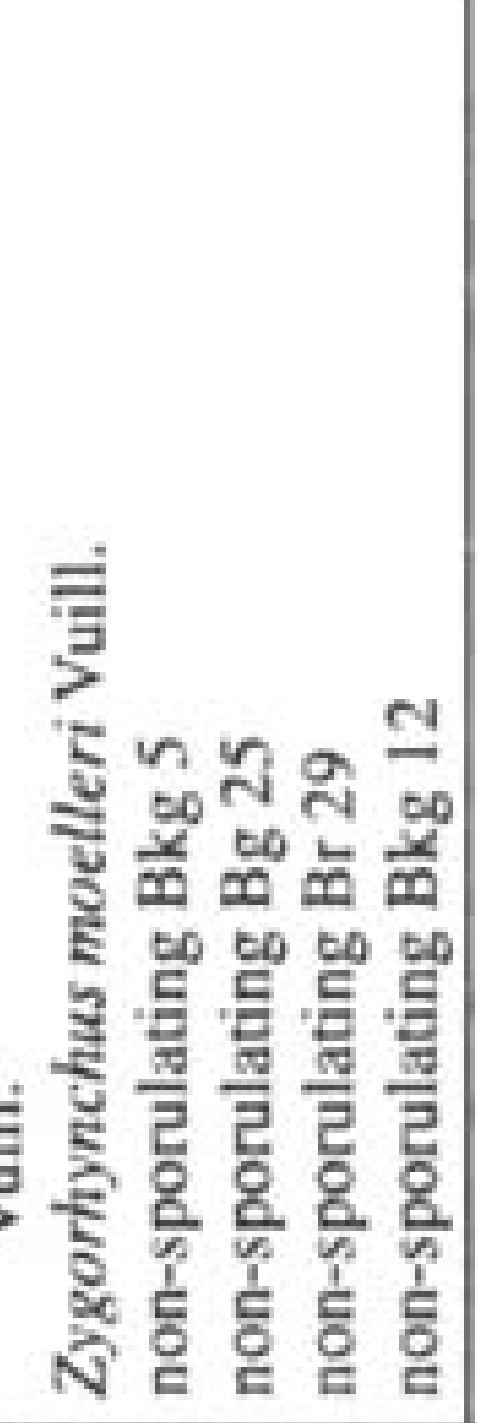 & & 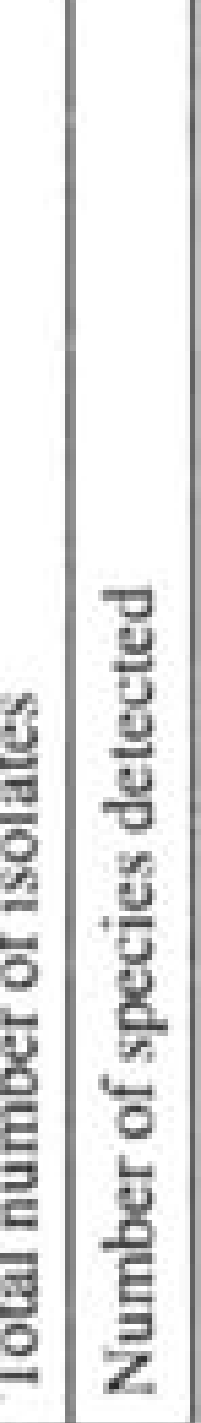 \\
\hline
\end{tabular}


Table 2

Frequency $(\%)$ of the most common taxa in soil, rhizoplane, rhizosphere, fine and thick roots of 49-year-old birch roots

\begin{tabular}{|l|cc|cc|cc|cc|cc|}
\hline \multirow{2}{*}{} & \multicolumn{2}{|c|}{ soil } & \multicolumn{2}{c|}{ thizoplane } & \multicolumn{2}{c|}{ rhizosphere } & \multicolumn{2}{c|}{ fine roots } & \multicolumn{2}{c|}{ thick roots } \\
\cline { 2 - 19 } & I & II & I & II & I & II & I & II & I & II \\
\hline Mucorales & 42.9 & 26.5 & 15.0 & 64.7 & 6.4 & 10.9 & 25.6 & 27.8 & 4.7 & 41.3 \\
Mycelium radicis atrovirens & 0 & 0 & 0 & 0 & 0 & 0 & 12.0 & 6.1 & 82.9 & 4.5 \\
Oidiodendron & 3.3 & 7.4 & 4.4 & 0 & 0 & 0.3 & 0 & 0 & 0 & 0 \\
Penicillium & 45.6 & 52.9 & 60.7 & 33.4 & 63.7 & 78.9 & 47.7 & 47.5 & 3.9 & 32.8 \\
Trichoderma & 0.1 & 0 & 0 & 1.0 & 0 & 0 & 8.7 & 16.7 & 0 & 6.6 \\
\hline
\end{tabular}

I- live trees

II - stumps

\section{DISCUSSION}

Armillaria obscura, A. bulbosa, A. borealis and A. mellea s.s. are the most common species of Armillaria complex occurring on the roots of coniferous and deciduous trees and their stumps in Poland (R y k o w s k i, 1990; M a ń k a, 1992). S h a w, K i l e (1991) claim that some Armillaria species may persist better on particular food base species, but there is still no evidence for substrate specialization. One of the opinion is that the hardwood stumps provide a better substrate than the living deciduous trees ( $\mathrm{M}$ a ń $\mathrm{k}$ a, 1992).

The environment has the significant effect on the infection by Armillaria. Many abiotic and some biotic environmental factors have so far been thoroughly studied ( $\mathrm{S} \mathrm{h}$ a w, K i l e, 1991). W a t a n a b e (1986) tested 121 fungal isolates for their ability to stimulate rhizomorph production either by co-culturing them with Armillaria or by enriching Armillaria culture media with culture broth of the tester strain. He observed that 37 of the isolates effectively induced rhizomorph growth. The most effective genera were: Macrophomina, Gliocephalis, Diploidia and Sordaria together with two unidentified species of Deuteromycotina. His reports did not include information on the chemical nature of the stimulatory factors involved. The species which were the most effective in the studies of W a t a $\mathrm{n}$ a b e (1986) do not belong to the most common in the soil/root habitat in Northern Europe forests. Thus, further information on the occurrence of saprophytic fungi on/in roots of the most common tree species and on the role of soil/root organisms in the process of infection is required. It seems that data regarding the structure of fungi communities as well as their influence on pathogen might help to explain the differences in degree of susceptibility to Armillaria infection. The first steps toward this were undertaken by $\mathrm{M}$ a n $\mathrm{k}$ a et al. (1993, 1993 a) and K w a śn a (1996 a, b, c).

Small amounts of low-molecular-weight alcohols and related compounds enhance Armillaria growth (W e i n h o 1 d, 1963). The mycelium growth and 
rhizomorph formation may be stimulated (W e i n h o l d, 1963; W e i n h o l d, $\mathrm{G}$ a r r a w a y, 1966). Injection of ethanol into roots of oaks promoted their colonization by Armillaria though W a r g o and M o n t g o m e r y (1983) claim that colonization in such the cases results more from the tissues necrosis caused by the ethanol than from the ethanol alone. The growth and development of Armillaria may also be promoted by other compounds, particularly auxines. Indole-3-acetic acid significantly increased rhizomorph production (G a r $r$ a w a y, 1975). According to the proposed mode of action, the interaction of auxin with the plasma membrane results in the release of a compound which controls the activity of RNA polymerase in the nuclei and stimulates the synthesis of mRNA. The new mRNA is translated in the cytoplasm where stimulates the production of the new proteins which enhance fungus cellular growth (K e y, 1969).

Soil microorganisms produce sufficient amounts of ethanol to promote rhizomorph production (P e n t 1 a n d, 1965, 1967). Indole-3-ethanol and indole-3-acetic acid are the major secondary metabolites produced by Zygorhynchus moelleri (B r o w n et $\mathrm{H}$ a m i $1 \mathrm{t}$ o $\mathrm{n}, 1992)$. Z moelleri was either the dominating or coodominating fungus on/in roots of 2 year-old stumps of 49 year-old birch where accounted for 3.4-52.9\% of the total number of isolates. On and in the fine roots of the live trees its frequency was only $1.6 \%$ and $3.3 \%$, respectively. In the soil surrounding both the roots of the live trees and of the stumps Z. moelleri was detected occasionally. Taking into account the size of fungi community on stump roots the density of Z. moelleri was considerably high and its presumably effect on the rhizomorph poduction might be conspicuous.

Larger amounts of indole-3-ethanol are produced at $\mathrm{pH}$ 6-7 and of indole-3-acetic acid at $\mathrm{pH} 4.5$. Under more acidic conditions, indole-3-ethanol may be transferred to roots where it can be utilized as the precursor for indole-3-acetic acid synthesis (B r o w n, H a m il t o n, 1992). In this situation it seems that the accumulation of Zygorhynchus moelleri may favour Armillaria growth and the infection of birch stump roots, under both more or less acidic conditions.

$\mathrm{Z}$ moelleri is also known to produce the phenoloxidase (D o $\mathrm{m} \mathrm{s} \mathrm{c} \mathrm{h,} \mathrm{G} \mathrm{a} \mathrm{m} \mathrm{s,}$ A n d e r s o n, 1980). This enzyme is very important in wood degrađation and it seems that it can stimulate the decay of roots which may intensify Armillaria infection.

It seems that the high density of Zygorhynchus moelleri might partly be due to the absence of bigger populations of Trichoderma viride on/in the birch stump roots. Trichoderma viride can invade Z moelleri (D u r r e l l, 1968) and eliminate it in the natural habitat. Trichoderma viride is considered to be a very effective antagonist of Armillaria ( $\mathrm{S}$ h a w, K il e, 1991). On/in birch stump roots T. viride occurred only sporadically in the rhizoplane and a bit more frequently in the thick roots. The fungus was detected more often $(6.2 \%$ of the total number of isolates) in the fine roots of the live trees. $T$. viride dominated in Scots pine stump roots and the increase of its frequency resulted in the inhibition of Armillaria growth in vitro ( $\mathrm{K}$ w a $\delta \mathrm{n}$ a, $1996 \mathrm{~b}$ ). This suggests the increase of pine stump roots resistance to 
pathogen in nature. Similar effect should not be expected on/in the birch stump roots, where $T$. viride was replaced by Trichoderma pubescens (former $T$. hamatum), which prefers more alkaline habitats of birch stumps and is totally ineffective towards Armillaria species ( $\mathrm{M} \mathrm{u} \mathrm{g}$ h o $\mathrm{g}$ h o, 1968).

The paper deals with the structure of fungi communities and discusses their possible role in promoting of the infection. The infection of roots in the live trees depends, however also on the host responses to pathogens which fall into three categories: exudate production, meristematic activity, and biochemical interaction. Deciduous trees respond to Armillaria by exuding gummy deposits into infected tissues ( $\mathrm{S}$ h a w, K i l e, 1991). Meristematic activity in the living roots leads to the production of cork, callus and adventitious roots. At the biochemical level fungal infection involves an interaction between compounds already present in the host or induced by infection and extracellular fungal metabolites. Preformed phenols and other host substances can inhibit the production of hydrolitic enzymes of Armillaria and restrict its activity on host cell walls and membranes. Some phenols can directly inhibit Armillaria growth. Other chemical changes in roots after tree felling might be similar to those after defoliation when the level of reducing-sugar increases particularly in cambial zone tissues (W a r g o, 1971). Since Armillaria predominantly utilizes glucose (W a r g o, 1981), this increase is potentially important to the fungus. The capacity of the dying or dead stump root tissues to respond and control the pathogen is reduced and it can increase the stump susceptibility to the infection. The specific composition of fungi communities should be, however also taken into account and considered as the factor increasing the predisposition of the stumps to Armillaria infection.

Further investigations on the effect of indole-3-ethanol and indole-3-acetic acid produced by Zygorhynchus moelleri on the growth and development of Armillaria rhizomorphs in vitro will be undertaken.

\section{REFERENCES}

B a sh a m J. T., 1988. Decay and stain 10 years later in aspen suckers subjected to scarification at age 3. Can. J. For. Res. 18: 1507-1521.

B row n A. E., Ha m i I t on J. T. G., 1992. Indole-3-ethanol produced by Zygorhynchus moelleri and indole-3-acetic acid analogue with antifungal activity. Mycol. Res. 96: 71-74.

D i m i t r i L., 1969. Untersuchungen uber die unteriridischen Eintrittspforten der wichtigsten Rotfauleerreger bei der Fichte (Picea abies Karst.) Centralbl. 88: 281-308.

Domseh K. H., G a m s W., A nde rs on T. H., 1980. Compendium of soil fungi. Academic Press, London, New York, Toronto, Sydney, San Francisco.

Du r re II L. W., 1968. Hyphal invasion by Trichoderma viride. Mycopath. Mycol. Appl. 35: 138-144.

$\mathrm{G}$ a $\mathrm{r} \mathrm{r}$ a $\mathrm{w}$ a y M. O., 1975. Stimulation of Armillaria mellea growth by plant hormones in relation to the concentration and type of carbohydrate. Eur. J. For. Ptath. 5: 35-43.

K e y J. L. 1969. Hormones and nucleic acid metabolism. An. Rev. Pl. Phys. 20: 449-474.

K i le G. A., 1981. Armillaria luteobubalinat a primary cause of decline and death of trees in mixed species eucalyptus forests in central Victoria. Austral. For, Res. 11:63-77.

$\mathrm{K} w$ a $\$ \mathrm{n}$ a H., 1996 a. Antagonistic effect of fungi from Scots pine fine roots on Heterobasidion annosum (Fr.) Bref and Armillaria ostoyae (Romagn.) Herink growth. Phytopath. Pol. (in print). 
$\mathrm{K}$ w a $S \mathrm{n}$ a H. , I $996 \mathrm{~b}$. Antagonistic effect of fungi from Scots pine stump roots on Heterobasidion annosum (Fr.) Bref and Armillaria ostoyae (Romagn.) Herink. Phytopath. Pol. (in print).

$\mathrm{K}$ w a $\$ \mathrm{n}$ a H., $1996 \mathrm{c}$. Fungal communities in soil beneath Scots pine and their stumps. Effect of fungi on Heterobasidion annosum and Armillaria ostoyae growth. Acta Mycol. 30; 193-205.

M a ń k a K., 1974. Zbiorowiska grzybów jako kryterium oceny wplywu srodowiska na choroby roslin. (Fungal communities as a criterion for estimating the effect of the environment on plant diseases). Zesz. Probl. Post. Nauk Roln. 160, 9-23.

M a ń $\mathrm{k}$ a K. 1992. Fitopatologia lesna. Paristwowe Wydawnictwo Rolnicze i Leśne. Warszawa. 402 pp.

Mań k a K., M ańka M., K was na H., La komy P., B a b ki e wi c z M., 1993. Zagrożenie sadzonek drzew leśnych przez patogeny korzeni a zbiorowiska grzybów ryzosferowch. Proc. IV Conf. Sec. Biol. Methods Plant Prot. Pol. Phytopath. Soc. Skierniewice, 7-13.

M a ń k a M., Ła k om y P., M a ćk owi a k Sz, 1993 a. Effect of thinning in Scots pine (Pinus sylvestris L.) stand growing on forest land, on supressiveness of soil to Heterobasidion annosum (Fr.) Bref, and Armillaria obscura (Schaeff) Herink. Phytopath. Pol, 6.55-60.

M u g h o g h o L. K., 1968. The fungus flora of fumigated soils. Trans, Br. Mycol. Soc. 51: $441-459$.

P e n $\mathrm{t} l$ a $\mathrm{n}$ d G. D. 1965. Stimulation of rhizomorph development of Armillaria mellea by Aureobasidium pullulans in artificial culture. Can. J. Microb. 11:345-350.

P e n t l a n d G. D., 1967. Ethanol produced by Aureobasidium pullulans and its effect on the growth of Armillaria mellea. Can. J. Microb. 13:1631-1639.

R i zzo D. M., H a r r i n g to n T. C., 1988. Root movement and root damage of red spruce and balsam fir on subalpine sites in the White Mountains, New Hampshire. Can. J. For. Res. 18:991-1001.

R y k ow s k i K., 1990. Opieńkowa zgnilizna korzeni. (Armillaria root-rot). PWRiL, Poznań, 1-16.

S h a w C. G. III, Ki le G. A., 1991. Armillaria root disease. For.Ser., U.S. Dep. Agric., 233 pp.

W a r g o P. M., 1971. Seasonal changes in carbohydrate levels in roots of sugar maple. Res. Pap. NE-213. Upper Darby, PA: U.S. Dep. Agric., North. Forest Exp. Station, 8 p.

W a r g o P. M., 1981. Defoliation and secondary-action organism attack: with emphasis on Amillaria mellea. Jour. Arboricult. 7:64-69.

W a r g o P. M., M on g o m m e r y M. E., 1983. Colonization by Armillaria mellea and Agrilus bilineatus of oaks injected with ethanol. Forest Sci. 29:848-857.

W a t a $\mathrm{n}$ a b e T., 1986. Rhizomorph production in Amillaria mellea in vitro stimulated by Macrophoma sp. and several other fungi. Trans. Myc. Soc. Jap. 27:235-245.

W e i n h o Id A. R, 1963. Rhizoinorph production by Amillaria mellea induced by ethanol and related compounds. Science. 142: 1065 - 1066.

W e i n h old A. R, G a r r a wa a y M. O., 1966. Nitrogen and carbon nutrition of Armillaria mellea in relation to growth-promoting effects of ethanol. Phytopathology. 56: 108-112.

Wh it n ey R. D., 1961, Root wounds and associated root rot of white spruce. For. Chronicle. 37:401-411.

\title{
Mikobionty korzeni brzozy oraz jej pniaków i ich przypuszczalny wpływ na porażenie przez Armillaria spp. I.
}

\author{
Streszczenie
}

Ryzoplana i ryzosfera oraz korzenie cienkie (0.5-1 mm sr.) i grubsze ( $5 \mathrm{~mm}$ sr.) 2-letnich pniakow powstalych przez scięcie 49-letnich brzóz byly zasiedlone przez większe zbiorowiska grzybów w porównaniu z drzewami żywymi. Najliczniejszym lub wiodącym gatunkiem na/w korzeniach pniaków byا Zygorhynchus moelleri. W ryzoplanie, ryzosferze, korzeniach cienkich i grubych pniaków jego udzial wynosil $52,9 \%$. $3,4 \%, 15,4 \%$ i $39,5 \%$ ogólnej liczby izolatow. Biorąc pod uwage wielkote zbiorowiska, populacja tego grzyba w ryzoplanie korzeni cienkich pniaków byla bardzo duża. Trichodema viride, antagonista grzybów $\mathrm{z}$ rodzaju Armillaria, nie wystapiła tak czessto, jak spodziewano sie; w korzeniach cienkich drzew żywych. jego populacja wynosiła $6,2 \%$, a w korzeniach pniaków spadla do poniżej $1 \%$ ogólnej liczby izolatów. W grubszych korzeniach pniaków populacja $T$. viride byla wyższa. Biorąc pod uwagę zdolnose Z moelleri do tworzenia kwasu 3-indolilooctowego i indolo-3-etanolu, które stymulują wzrost ryzomorf Armillaria spp. oraz enzymu, oxydazy fenolowej umożliwiającej rozklad drewna, wzrost populacji tego grzyba przy braku obecnosci $T$. viride może stwarzać w korzeniach pniaków brzóz lepsze warunki dla infekcji ze strony Amillaria spp., niž w korzeniach drzew żywych. 